\title{
Concentrations of Progesterone During Storage of Whole Blood from Llama (Lama glama): Effects of Anticoagulants, Storage Time and Temperature
}

Reproductive studies usually utilizes measurement of progesterone in various fluids such as plasma, serum or milk. It has been shown that progesterone concentrations in bovine whole blood decrease proportionally to: i) the time elapsed between the collection of the sample and the separation of plasma or serum from the erythrocytes and ii) the temperature of storage during this period (Breuel et al,1988, Pulido et al.1991). The addition of anticoagulants cause a more rapid decline in progesterone concentrations (Wiseman et al. 1982). In equine, porcine and canine blood samples storage time and temperature has a negligible effect on progesterone concentrations (Wiseman et al. 1982; Oltner \& Edqvist 1982). Cordero et al. (1991) working with llama and alpaca whole blood, treated with EDTA as anticoagulant, reported a slight progesterone metabolization in alpaca plasma, but not in llama plasma.

The objective of the present study was to evaluate the effects of incubation time and temperature of whole blood from llamas on progesterone concentrations in serum and plasma with sodium heparin and sodium fluoride as anticoagulants.

Blood samples were obtained from 3 pregnant llamas, between month 5 and 7 of gestation. Animals were kept on a natural pasture in the natural reservation "Sierra del Tigre", Tandil, Buenos Aires province, Argentina.

From each animal $240 \mathrm{ml}$ of jugular vein blood was obtained. The blood was immediately divided into 3 equal fractions: $\mathrm{S}=$ without anticoagulant; $\mathrm{H}=$ containing $0.1 \mathrm{mg} / \mathrm{ml}$ sodium heparin and $\mathrm{F}=$ containıng $10 \mathrm{mg} / \mathrm{ml}$ sodium fluoride. Blood from each fraction was further separated into 17 aliquots of $4 \mathrm{ml}$ each. One was immediately centrifuged and the remaining 16 were divided into 2 groups. One group was kept refrigerated at $4^{\circ} \mathrm{C}$ and the second in an incubator at $25^{\circ} \mathrm{C}$. For each anticoagulant treatment ( $\mathrm{S}, \mathrm{H}$ and $\mathrm{F}$ ), aliquots from every animal and storage condition were centrifuged after $0.5,1,2,3,4,6,8$ and $24 \mathrm{~h}$. After centrifugation, plasma and serum was separated immediately and kept frozen at $-20^{\circ} \mathrm{C}$ until assayed.

Progesterone was assayed using solid-phase RIA kits without previous extraction (Coat-ACount Kit, Diagnostic Products Company, Los Angeles, California, USA), generously provided by the International Atomic Energy Agency, Vienna, Austria. The inter-assay coefficient of variation calculated from 3 assays was below $12 \%$ for concentrations between 2-80 nmol $1^{-1}$. All samples from one animal were assayed in a single assay to avoid inter-assay variation. The intra-assay coefficients of variation were $9.1 \%$ and $7.2 \%$ for samples containing 4.8 and $12.0 \mathrm{nmol} \mathrm{l^{-1 }}$ respectively. The detection limit of the assay was $0.4 \mathrm{nmol}^{-1}$.

For each animal, the progesterone concentrations measured in the aliquots centrifuged immediately after collection from the $\mathrm{S}, \mathrm{H}$ and $\mathrm{F}$ 
treatments were defined as $100 \%$. All subsequent progesterone concentrations were expressed in $\%$ of the individual initial value. Data were then analyzed by analysis of variance as a $3 \times 2 \times 9$ factorial experiment in a randomized complete block design with treatment $(\mathrm{S}$, $\mathrm{H}$ and $\mathrm{F}$ ), storage temperature $\left(4\right.$ or $25^{\circ} \mathrm{C}$ ) and storage time $(0,0.5,1,2,3,4,6,8$ and $24 \mathrm{~h})$ as the main effects (Steel \& Torrie 1980).

The mean ( \pm s.e.m.) progesterone concentration in the samples centrifuged immediately after blood collection was $7.6 \pm 1.2 \mathrm{nmol}^{-1}$. The presence of anticoagulants did not affect the measurement of progesterone ( $p>0.05$ ). Mean initial concentrations of progesterone for $\mathrm{S}, \mathrm{H}$ and $F$ treatments were $7.4 \pm 1.3 ; 7.3 \pm 1.0$ and $7.3 \pm 0.3 \mathrm{nmol} \mathrm{l}^{-1}$, respectively. None of the main effects were significant $(p>0.05)$. The effect of the blocking variable (individual anımal) indicated differences in progesterone concentration, which could be expected between different llamas $(p<0.05)$.

There was no significant effect of storage temperature on the concentration of progesterone across time ( $>00.05)$. After $24 \mathrm{~h}$, the recovered concentrations of progesterone were $98.9 \pm$ 13.9 and $105.1 \pm 14.6 \%$ of the initial concentration for samples stored at $4^{\circ} \mathrm{C}$ and $25^{\circ} \mathrm{C}$, respectively.

Since no significant differences were detected between storage temperature, results from $4^{\circ} \mathrm{C}$ and $25^{\circ} \mathrm{C}$ were pooled when calculating the final recovery for each treatment over time. No significant differences were observed across time in serum samples and plasma samples containing sodium heparin and sodium flouride $(p>0.05)$. The overall progesterone concentration measured in the aliquots centrifuged after $24 \mathrm{~h}$ was in average $102.03 \pm 14.6 \%$ of the mean initial concentration $(n=18)$. For the $S, H$ and $\mathrm{F}$ treatments, the values after $24 \mathrm{~h}$ were: $108.9 \pm 15.1,102.6 \pm 14.04$ and $94.7 \pm 10.6 \%$ of the initial concentration, respectively.
The progesterone levels in this study are within the range previously reported in llamas with a functional corpus luteum (Adam et al. 1989, Leon et al. 1990). The biochemical metabolization of progesterone by cellular components reported in bovine whole blood (Vahdat et al. 1979) was not observed in llama blood. This observation is in accordance with results previously reported by Cordero et al. (1991) working with llama blood and EDTA as anticoagulant. In contrast to bovine plasma and serum (Wiseman et al. 1982, Pulido et al. 1991), there were no significant differences between final progesterone concentrations in llama serum and plasma when heparin and sodium fluoride were used as anticoagulants and final progesterone concentrations were not influenced by storage time and temperature. Thus, if facilities to refrigerate samples are lacking, it is still possible to measure accurate concentrations of progesterone in llama blood samples stored at room temperature for $24 \mathrm{~h}$ before centrifugation.

MA Abal ${ }^{* 1}, M$ Ghezzl $^{2}, M$ Quiroga ${ }^{2}, H$ Solana $^{2}$ and $N A u z a^{2}$

${ }^{1}$ Department of Clinical Chemistry, Faculty of Veterinary Medicine, Swedish University of Agricultural Sciences, Uppsala, Sweden and ${ }^{2}$ Department of Physiopathology, Faculty of Veterinary Sciences, U. N.C., Tandıl, Buenos Aıres, Argentına.

* Permanent address Department of Physiopathology, Faculty of Veterinary Sciences, U.N.C.P.B A., Paraje Arroyo Seco, Tandil, -7000- Buenos Aires, ARGENTINA.

\section{References}

Adam CL, Moir CE and Shiach P. Plasma progesterone concentration in pregnant and nonpregnant llama (Lama glama). Vet. Rec. 1989, 125, 618620.

Breuel KF, Spitzer JC, Gimenez T, Henricks DM and Gray $S L$. Effect of holding time and temperature of bovine whole blood on concentration of Progesterone, Estradiol - 17ß and Estrone in plasma and serum samples. Theriogenology 1988, 30, 613-627. 
Cordero RA, San-Martin FH, Echeverría LC, Huanca $W L$, Casas HP and Sumar $J$ Progesterona Plasmática en alpacas y llamas: temperaturas y tiempo previos a la centrfugación Rev Inv Pec. IVITA. 1993, 6, 41-45.

Leon JB, Smith BB, Timm KI and LeCren G Endocrine changes durıng pregnancy, parturition and the early post-partum period in the llama (Lama glama) J Reprod Fert 1990, 88, 503-511

Oltner $R$ and Edqvist LE Changes in plasma progesterone levels during storage of heparinızed whole blood from cow, horse, dog and pig. Acta vet. scand. 1982, 23, 1-8.

Pulıdo A, Zarco L, Galina CS, Murcia C, Flores $G$ and Posadas $E$ Progesterone metabolısm during storage of blood samples from Gyr cattle: Effects of anticoagulant, time and temperature of incubation. Theriogenology 1991, 35, 965-975

Steel RED and Torrle $J$ Principles and procedures of Statıstıcs. McGraw - Hill, NewYork, NY, 1980, pp 173 and 336

Vahdat F, Hurtgren JP, Whitmore HL, Johnston SD and Ketelsen $C L$. Effect of time and temperature on bovine serum and plasma progesterone concentration. Theriogenology 1979, 12, 371-374.

Wiseman BS, Vincent DL, Thomford PJ, Scheffrahn $N S$, Sargent GF and Kesler DJ Changes in porcine, ovine, bovine and equine blood progesterone concentrations between collection and centrifugation. Anım. Reprod Sc1. 1982, 5, 157165.

(Recelved May 17, 1995; accepted November 31, 1995).

Reprints may be obtained from M.A. Aba, Department of Physiopathology, Faculty of Veterınary Sciences, UN C.P.B.A., Paraje Arroyo Seco, Tandıl, 7000 Buenos Aires, Argentına. 